\title{
LXVII. On the cosmogony of Moses
}

\section{Mr. Andrew Horn}

To cite this article: Mr. Andrew Horn (1816) LXVII. On the cosmogony of Moses, Philosophical Magazine Series 1, 47:217, 339-344, DOI: 10.1080/14786441608628474

To link to this article: http://dx.doi.org/10.1080/14786441608628474

曲 Published online: 27 Jul 2009.

Submit your article to this journal $\pi$

LII Article views: 2

Q View related articles $₫$ 
that the juice has ceased rumning from the presses it will already have acquired from forty to fifty degrees of heat, which is suffered to increase to sixty-five or sixty-six degrees, and the moment it has attained this heat the fire is smothered by covering it with wet coals. Lime, slaked with warm water, is then thrown into the boiler, in the proportion of two grammes and a half (about forty-eight grains) to a litre of juice, heing careful to vary the vroportion according to the consistence of the juice. The liquid mass must be well stirred, in all directions, for some minutes, and then the fire is revived, in order to raise the heat to eighty degrees; that is, to the degree nearest approaching to ebullition. The fire is then taken out of the fire-place, and as the liquor cools a coat forms on its surface, which in half an hour has acquired a degree of consistence, which at the end of three quarters of an hour is carefully taken off with the scum. As soon as it is stimmed, a cock is turned, which is fixed about a foot from the bottom of the boiler, and the liquor runs out into a square boiler; afterwards a second coek is opened, which is quite at the bottom of the boiler, in order to empty it entirely, and the liquor is made to fall upon a filter, through which it also rums into the square boiler.

[To be continued.]

LXVII. Onthe Cosmogony of Moses. By Mr. Andnew Horn.

To Mr. Tilloch.

Sir, $-\mathrm{H}_{\text {Aving in my former communication shown that the }}$ term $d a y$, as used in designating the six periods of the Genesis, properly denotes one revolution, whether slow or rapid, of the earth upon its axis, which produced a morning and an evening successively upon every meridian on the globe, my object in the present paper is to rectify some misconceptions of your correspondents, respecting certain parts of the Cosmogony connected with those periods.

The statement of faets enumerated by Dr. Prichard, p. 287 of your last volume, is I conceive just, with the exception of the three articles where he says " the water had subsided before the creation of organized beings." But this perhaps is one of those verbal maccuracies which he hints at in your last number. Your eorrespondent F. E-S has committed the same mistake at p. 181 of the present volume, in which he remarks, that "the waters retire previous to the existence of animated beings, and never again cover the earth until the days of Noah." On this error he founds a plausible objection against the Cosmogony, and 
endeavours to support it by a reference to geological phæenomena. The only passage in the Genesis, from which any such inference could be drawn, is the following, ver. 9, "Let the waters be gathered together to one place, and let the dry land appear." This construction seems somewhat to favour the error. The Hebrew, however, is in the future tense, and literally, "the waters shall tend to one place, and the dry land shall appear: and it was so." Moses uses the same original word, Gen, chap. viii. ver. 5, to describe the first appearance of the mountains at the deluge: "The waters decreased continually until the tenth month: in the tenth month, on the first day of the month, were the tops of the mountains secn." But the waters of the deluge "were not abated from off the earth' for some months afterwards. Now it is no more possible that the earth could have been instantaneously laid dry, when the mountains emerged out of the primitive ocean, than when they showed themselves above the waters of the deluge. The formation therefore of the dry-land at the creation was gradual, and the subsidence of the waters in proportion to the means employed to drain them off. The manner in which this was effected does not at present concern us. It is evident, then, that the waters only began to subside, when the dry-land appeared. How long it was before they sunk to a fixed level never can be ascertained. Ages might have elapsed, even after the land animals were created, before the waters had completely subsided. Hence, to say nothing of the probable rapidity of the depositions, since the period between the elevation of the land to the complete subsidence of the waters is indefinite, I feel confident in the assertion, that it was sufficient for the formation of all the strata at lower and lower levels, from the clay-slate down to the chalk rocks, which are supposed to be among the last deposits of the primitive ocean; and, as the retreat of the waters was from the equatorial parts towards the polar regions, these calcareous rocks are accordingly found only in the higher latitudes.

It has been generally, but erroneously supposed that each operation was completed within the period in which it is first mentioned; and that the day was solely orcupied by that particular object; whereas the subject is sometimes noticed, bccause it then began to be formed; at other times it is specified, because it then proved actually fit for the purpose for which it was designed. 'Thus the other is pronounced ' good' on the first day, because, as soon as it reached the earth the globe was put in motion by it. The expanse or atmosphere began to be formed, but was not completed on the second day; nothing but the other is declared 'good' or fit until the third day, in which the dry-land appeared and vegetables began to be produced; nor is 
the sun itself pronounced fit for its office until the end of the fourth day.

In order to correct certain mistakes, and obviate some cbjections to the Cosmogony, I shall, for the sake of brevity, enumerate, as Dr. Prichard has done, the facts in the Genesis, and, without drawing a parallel between them and the geological phænomena, shall only insert such observations as may be necessary for my purpose.

1. All the substances of which the earth is composed were once in a state of atomic division. The waters of the ocean universally covered for a long period the whole mass, and by chemical action formed what are called primitive rocks. But it is impossible from any present process of crystallization, to judge of the rapidity with which the original atoms were crystallized, and strata formed by their aggregation.

2. No organic beings existed in the primitive ocean till after the mountains were elevated.

3. The mountains emerged out of the ocean at the commencement of the third period. 'The waters then began to subside, but still continued to form strata, and in proportion as they left the land dry, vegetables were produced.

The production of zoöphytes and testacea is justly referred by Dr. Prichard to this epoch; because they are destitute of locomotive powers, which Moses positively assigns to all the productions of the fifth period. The objections which F.E-s has raised to this statement, when his collateral matter is removed, amounts to this-" Moses, it is true, expressly says that all the aquatic locomotive animals were produced in the fifth period, but he does not sfecifically determine in what period zoöphytes and testacea were produced; therefore the parallel fails between the facts detailed in the Genesis and those inferred from geological phænomena." But surely this is such a test as no author can endure; at most, it can in justice only be applied to those professedly systematic. Has Moses, in relating the periods of creation and order of things in the formation of this earth and its inhabitants, indecd given a false representation of nature, because he has omitted to mention one or two particular species of animated beings? Does he not at the conclusion of the narrative say, "Thus were the heavens and the earth finished, and all the host of them." This mode of expression is equivalent to that in the fourth commandment, "In six days the Lord made heaven and earth, the sea and all that is in them." Now it is highly unreasonable, to say the best of it, when an author gives the limits of his premises, to deny that he means to include all the intermediate terms. What should we think of the Y 3 
person that could question, whether another had travelled every inch of the road from London to Edinburgh, through York and Newcastle, merely because he had not named every other intervenient stinge? Must the Cosmogony then be exploded, becanse the author has not marked every link in the chain of organization? - because he has neither pointed out the precise limit between animal and vegetative life, nor distinguished the formation of aquatic plants from those belonging to the land, nor named the species which conjoins the locomotive animals of the fifth with those of the sixth day? Should we, it seems according to the reasoning of your correspondent F.E—s, assign the bat species to the fifth day, "we place an order of locomotive beings where Moses has not placed them." But though " it is absolutely certain that Moses assigns them" to neither of these periods, he; as certainly, never designed to exclude from the Cosmogony either the irat species, which connects the bocomotive animals of the fifth with those of the sixth day, or zoöphytes and testacea, which link the organized productions of the fifth with those of the third day. Having described the order in which the grand classes of organized beings were produced, he leaves us to systematize, and make our own physiological distinctions. So imperceptible is the gradation of species among organized beings, that it is only within these few years naturalists have thought proper to transfer corals, \&c. from the rank of vegetables, among which they were classified as fungitce, and arrange them as animals under the technical name of zoöphytes. Even testrcea do not lose all analogy to vegetables, though they rank higher in the scale of existence than zoöphytes, and, agreeably to the tenor of the narrative, were probably created somewhat later. Testacea approach very near to vegetative life; their stationary disposition, and their receiving nutriment by suction, most likely from the same substances with aquatic plants, give them no small resemblance to vegetables. In short, they seem a kind of animated fungi, compared with the locomotive animals that subsist around them.

Whatever coincidence may be discovered between the above reasoning and that of Dr. Prichard, in his answer to F. E-s, is entirely accidetital ; for the whole paragraph was written before I received your last number. But I ought rather to have said that our agreement necessarily arises from an impartial view of the question.

4. The waters continuing to decrease, the regetable kingdom became more and more extended, till the conclusion of the fourth day, when the sun by its regular operation produced a corresponding regularity in the motions of the earth, which was now rendered 
reacuered fit for the reception of beings of a more perfect character than vegetables, or those motionless concretions of animated matter, zoöphytes and testacea.

5. In the fifth period aquatic locomotive animals were produced, the waters being now sufficiently purified for their reception. Dr. Prichard has well observed, that locomotion is the precise meaning of the Hebrew word used to distinguish this class of organized beings. It is not a little remarkable that to this period Moses assigns the production of birds. 'Though they are by internal organization constituted for living in air, their locomotive powers certainly have a nearer relation to those of fishes than to the powers of locomotion in land animals. Another reason, besides the perishable nature of their bones, may be assigned for their remains being so rarely found; viz. they are better provided with the means of escape from sudden inusdations than land animals, or even fishes, in certain situations.

Moses notices a class of aquatic animals, in the productions of this period, which our translators have rendered ' great whales ;' but literally the phrase ought to be 'great monsters ;' which will include not only existing crocodiles, hippopotami, \&c. but also those large marine animals found in different parts of this country as well as upon the continent, embedded in the lyas or argillaceous limestone, and, until very lately, erroneously supposed to be crocodiles.

6. The various species of land reptiles and quadrupeds were produced early on the sixth day.

7. Every thing being thus prepared for their reception, the rationad species is lastly formed; and the whole ceconomy of nature being pronounced 'very good,' man is irvested by the Creator with dominion over all the inferior creatures.

It is with reluctance that I remark upon what Dr. Prichard has advanced, p. 259 of your last number. In defending Moses as an inspired writer, he says that the Egyptians were possessed of " the most authentic documents that existed concerning the history of the world." An opinion which he assumes on the authority of Michaelis, who embraces the hypothesis of Marsham in his Rule of Times, - " that Moses framed his code of laws by combining the ancient usages of the nomadic Hebrews with the institutions of the agricultural Egyptians." Now, however well calculated the hypothesis may be for displaying the learning of the German professor, his erudition is of no weight, when put in the scale against the plain and positive language of Scripture; Lev. chap. xviii. ver. 3-4. "After the doings of the land of Egypt wherein ye dwelt, shall ye not do: neither shall ye walk in their ordinances. Ye shall do my judgements, and keep mine ordinances, to walk therein: I am Jehovah your God." 
Whatever use Moses might make of the Egyptian documents in composing his Cosmogony, he certainly had a purer source from whence to draw his information. The Hebrews and their ancestors were worshippers of the true God; therefore the listory of the origin of the world is more likely to have been preserved pure by them than among the idolatrous Egyptians. Superstition never was favourable to truth. Traditional facts are also more safe with a nomadic than a civic people. They have fewer subjects to burthen the memory, and less temptation to corrupt them.

The perseverance of Dr. Prichard in his original intention of proving the Mosaic Cosmogony " capable of a rational and philosophical interpretation" is laudable; and the near approaches he has made to this, particularly in p. 262, 263 of your last number, are important results from the repeated attacks of his opponent. But having assumed an untenable position respecting the term day, he is forced, p. 260, to advance some unwarrantable opinions in order to support it. The supposition that the Hebrews were anthropomorphites must -rest upon evidence from their writings. Now if we are to determine the national belief from their religious institutes and theology of their other scriptures, they were, as a nation, the furthest of all others from anthropomorphism. All other nations were idnlaters, and, in general, conceived the most perfect image of the Deity must be the likeness of man. The Hebrew writers are unequalled in speaking of the spirituality of God; and where they speak of the eyes, arms, \&c. of Jehovah, these expressions, in the connexion in which they stand, no more favour anthropomorphism than the term father itself, as applied to the Author of life. With respect to the expression "God rested;" it would be more agreeable to the spirit of the original, to render it ceased;"God ceased from all his work, which he created, לע' to operate," as ver. 3 , chap. ii. of the Genesis, ought to be rendered.

I am, sir,
Wycombe, May 8, 1816.

LXV111. Description of an electrical Instrument called "The Thunder-storm Alarum." By B. M. Forster, Esq.

To Mr. Tilloch.

Sir, - I herewith hand you a description and figure of an eleetrical instrument, which may I think with propriety be called 